\title{
Variation in the ice cover thickness on Lake Samołęskie as a result of underground water supply
}

\author{
Adam Choiński, Mariusz Ptak \\ Institute of Physical Geography and Environmental Planning, Adam Mickiewicz University, Dzięgielowa 27, 61-680 Poznań, Poland, e- \\ mail: choinski@amu.edu.pl,marp114@wp.pl

\begin{abstract}
The character of phenomena related to freezing depends on macroscale factors and mainly on thermal conditions, but local conditions can also be of great importance in shaping the course of these phenomena. Building of ice cover can be substantially different even for neighbouring lakes as a result of different individual features such as, for example, morphometric parameters. In this study the variation in the thickness of ice cover on Lake Samołęskie (29 ha) localised in western Poland, is analysed. According to measurements performed the differences in the thickness of ice cover was significant as it varied from 20 to $33 \mathrm{~cm}$. A characteristic feature was that along the west bank of the lake the ice cover was thinner and its thickness increased towards the east. Analysis of the hydrogeological data revealed that this phenomenon is related to the supply of water to the lake basin by efficient water-carrying formations. The influx of water affects the bottom layer of the ice cover. This effect is aggravated by the fact that the water is supplied under elevated pressure as evidenced by the presence of a polynia of about $10 \mathrm{~m}$ in diameter, over the deepest (over 20 metres deep) site in the lake. The polynia is never frozen, even during the coldest winters. The specific features of the lake illustrate the influence of local geological conditions on the character of processes taking place in lakes in general.
\end{abstract}

Keywords: lakes, ice cover, underground water supply

\section{Introduction}

The processes taking place in lakes are determined by a combined influence of a number of factors. Usually macroscale factors such as thermal conditions, amount and kind of precipitations are taken into account, so lakes within the same regions are assumed to have similar conditions of functioning. The regions are distinguished on the basis of, for example, catchment area and type of lakeland, so lakes from the same regions are assumed to be similar. However, it is not always the case: some lakes even when lying at close distances can show significantly different features reflecting individual features of the lake catchment area and its basin. The main factors responsible for such differences are the morphometry of lake basins, the use of the catchment area, character of flow and geological structure. The latter factor, similar to the macroscale factors, is difficult or impossible to be altered by humans. Of course there are such sites at which the geological structure is transformed by people, such as opencast mines, but they need substantial investment and have strict economic justification. Thus, it can be assumed that the geological structure of a given part of land where the lake basin is located, along with the macroscale factors, determine its functioning.

Relations of lakes with underground water have been the subject of interest of many authors (PiekarekJankowska 1973; Sacks et al. 1992; Winter 1999, Smerdon et al. 2005; Choiński et al. 2008; Yin L et al. 2011; Kettle et al. 2012). However, not much attention has been paid to the influence of the underground water supply on the character of freezing phenomena on lakes. One of the very few works describing an example of such a relation is that by Choiński et al. (2008). Of particular importance in this context is the character of ice cover that can isolate water from external influence, even for a few months, and can cause oxygen deficit. The paper presents preliminary results on differences in the thickness of ice cover of Lake Samołęskie, which is intensely supplied with underground water. 


\section{Study area and methods}

The object of study was Lake Samołęskie localised, according to Kondracki (1987), in the macroregion of the Greater Poland Lakeland (315.5) and its mezoregion the Poznan Lakeland (315.51), at about 50 $\mathrm{km}$ north-west of Poznań (Fig. 1). The main parameters of the lake are presented in Table 1.

As follows from the parameters presented in Table 1, Lake Samołęskie has rather a great maximum depth and a relatively small area, but these features are not unique in the scale of the country. More interesting and unique is the surrounding or the lake - its west bank is a few-metre-high escarpment (Fig. 2), while the other banks have gentle slopes.
Table 1. Morphometric data for Lake Samołęskie (according to IIF)

\begin{tabular}{cc}
\hline Altitude [m a.s.I.] & 59.0 \\
Surface [ha] & 29.0 \\
Maximum length [m] & 1260.0 \\
Maximum width [m] & 280.0 \\
Volume [dam $\left.{ }^{3}\right]$ & 2567.5 \\
Maximum depth [m] & 22.2 \\
Mean depth [m] & 8.9 \\
\hline
\end{tabular}

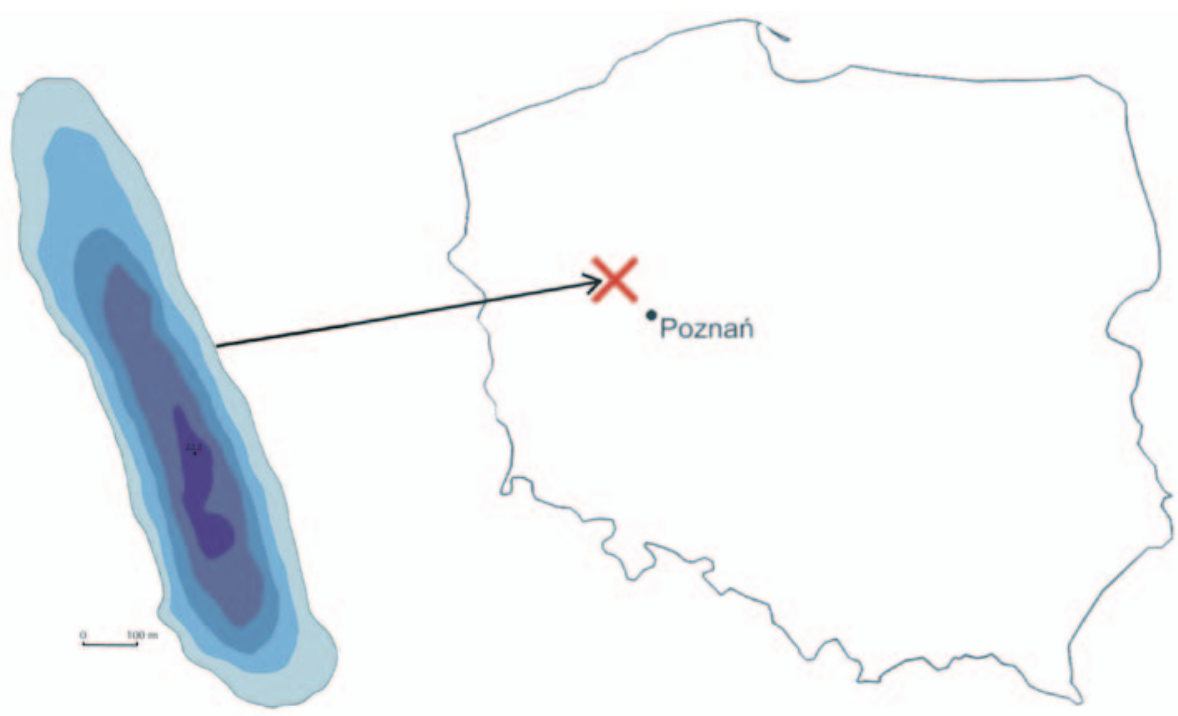

Fig.1. Localisation and bathymetric plan of Lake Samołęskie, according to the Institute of Inland Fishery (IIF 1961)
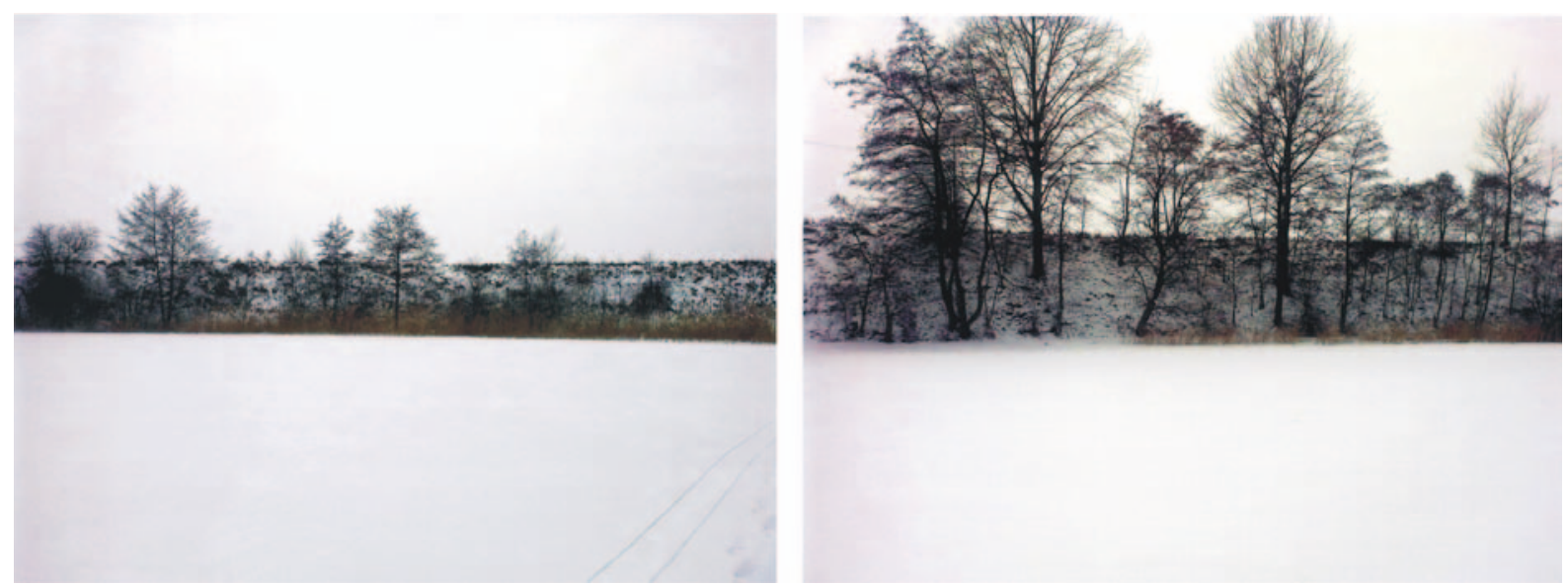

Fig. 2. The west bank of Lake Samołęskie 
In the above context, it was interesting to analyse the hydrogeological conditions of Lake Samołęskie. It is localised in I A- Region of Wronki (Pękacki and Ziółkowski 1985. The main usable water horizon of this region belongs to tertiary formations of a thickness from 40 to $100 \mathrm{~m}$ lying directly beneath the quaternary formations of rather small thickness ranging from a few to fewer than twenty metres. The efficiency of these formations is very high and near Lake Samołęskie it reaches $120 \mathrm{~m}^{3} \mathrm{~h}^{-1}$. Water in these horizons can be under pressures reaching over $100 \mathrm{kPa}$, which can produce artesian flow. The field study aimed at measuring the thickness of ice cover was made on February 13th, 2012. Altogether 21 holes were drilled in the ice cover over the entire lake area and the ice cover thickness was measured. The drilling was made by a bore made by Husqvarna (Fig. 3 ) with an internal combustion engine, while the ice cover thickness was measured with a measuring rod. The localisation of the holes was described with the use of a GPS12 Garmin.

Results of the measurements were marked on the map of the lake and after interpolations the differences in the ice cover were illustrated.
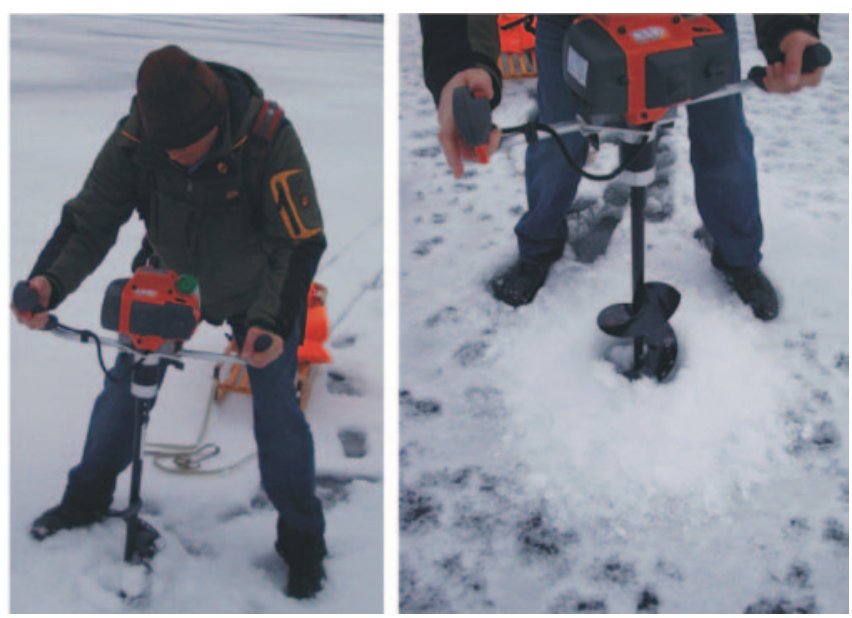

Fig. 3. Drilling holes

\section{Results}

Measurements of ice cover were preceded by a field reconnaissance to establish that on the day of measurements the lake was not supplied by any surface inflow and there was only one outflow in the northern part of the lake. Moreover, in the central part of the lake, towards its southern part, the presence of polynia of about $10 \mathrm{~m}$ in diameter was observed. On the basis of an interview with local fishermen it was established that the polynia appears every winter (irrespective of temperatures) and remains in this spot to the end of winter. Results of the ice cover measurements are given in Table 2 .

Table 2. The thickness of ice cover on Lake Samołęskie (13.02.2012)

\begin{tabular}{|c|c|c|c|}
\hline Site coordinates & $\begin{array}{l}\text { Ice thickness } \\
{[\mathrm{cm}]}\end{array}$ & Site coordinates & $\begin{array}{l}\text { Ice thickness } \\
{[\mathrm{cm}]}\end{array}$ \\
\hline $\begin{array}{l}52^{\circ} 41.275^{\prime} \\
16^{\circ} 25.184^{\prime}\end{array}$ & 28 & $\begin{array}{l}52^{\circ} 41.106^{\prime} \\
16^{\circ} 25.318^{\prime}\end{array}$ & 30 \\
\hline $\begin{array}{l}52^{\circ} 41.256^{\prime} \\
16^{\circ} 25.179^{\prime}\end{array}$ & 29 & $\begin{array}{l}52^{\circ} 41.084^{\prime} \\
16^{\circ} 25.290^{\prime}\end{array}$ & 30 \\
\hline $\begin{array}{l}52^{\circ} 41.233^{\prime} \\
16^{\circ} 25.166^{\prime}\end{array}$ & 29 & $\begin{array}{l}52^{\circ} 41.064^{\prime} \\
16^{\circ} 25.258^{\prime}\end{array}$ & 20 \\
\hline $\begin{array}{l}52^{\circ} 41.214^{\prime} \\
16^{\circ} 25.145^{\prime}\end{array}$ & 21 & $\begin{array}{l}52^{\circ} 41.060^{\prime} \\
16^{\circ} 25.305^{\prime}\end{array}$ & 24 \\
\hline $\begin{array}{l}52^{\circ} 41.199^{\prime} \\
16^{\circ} 25.192^{\prime}\end{array}$ & 28 & $\begin{array}{l}52^{\circ} 41.040^{\prime} \\
16^{\circ} 25.364^{\prime}\end{array}$ & 30 \\
\hline $\begin{array}{l}52^{\circ} 41.199^{\prime} \\
16^{\circ} 25.225^{\prime}\end{array}$ & 29 & $\begin{array}{l}52^{\circ} 41.015^{\prime} \\
16^{\circ} 25.337^{\prime}\end{array}$ & 30 \\
\hline $\begin{array}{l}52^{\circ} 41.181^{\prime} \\
16^{\circ} 25.256^{\prime}\end{array}$ & 27 & $\begin{array}{l}52^{\circ} 40.589^{\prime} \\
16^{\circ} 25.296^{\prime}\end{array}$ & 30 \\
\hline $\begin{array}{l}52^{\circ} 41.166^{\prime} \\
16^{\circ} 25.226^{\prime}\end{array}$ & 32 & $\begin{array}{l}52^{\circ} 40.573^{\prime} \\
16^{\circ} 25.336^{\prime}\end{array}$ & 30 \\
\hline $\begin{array}{l}52^{\circ} 41.149^{\prime} \\
16^{\circ} 25.202^{\prime}\end{array}$ & 24 & $\begin{array}{l}52^{\circ} 40.571^{\prime} \\
16^{\circ} 25.380^{\prime}\end{array}$ & 30 \\
\hline $\begin{array}{l}52^{\circ} 41.136^{\prime} \\
16^{\circ} 25.260^{\prime}\end{array}$ & 33 & $\begin{array}{l}52^{\circ} 41.480^{\prime} \\
16^{\circ} 16.240^{\prime}\end{array}$ & 27 \\
\hline $\begin{array}{l}52^{\circ} 41.129^{\prime} \\
16^{\circ} 25.291^{\prime}\end{array}$ & 32 & & \\
\hline
\end{tabular}

As follows from the above data, the differences in the ice cover thickness on Lake Samołęskie are significant as they reach as much as $13 \mathrm{~cm}$ over a rather small lake area. The changes in the ice cover are illustrated in Figure 4. It should be mentioned that on the day of drilling holes the air temperature was nearly minus $20^{\circ} \mathrm{C}$; similar air temperatures oscillating between $-10^{\circ} \mathrm{C}$ and $-20^{\circ} \mathrm{C}$ had been noted over the ten days before the date of measurements.

According to the results, the thickness of ice cover did not change at random but showed a regularity, i.e. in general it increased from the west to the east. The line of the thinnest ice cover corresponded to the line of the escarpment on the west bank of the lake. With decreasing slope of the banks, the ice cover thickness increases, Figure 5.

The distribution of the thickness of ice cover proves that the water bearing horizons are more intensely drained on the west side of the lake. Taking into account the hydrological conditions described above, the differences in the ice cover thickness imply 


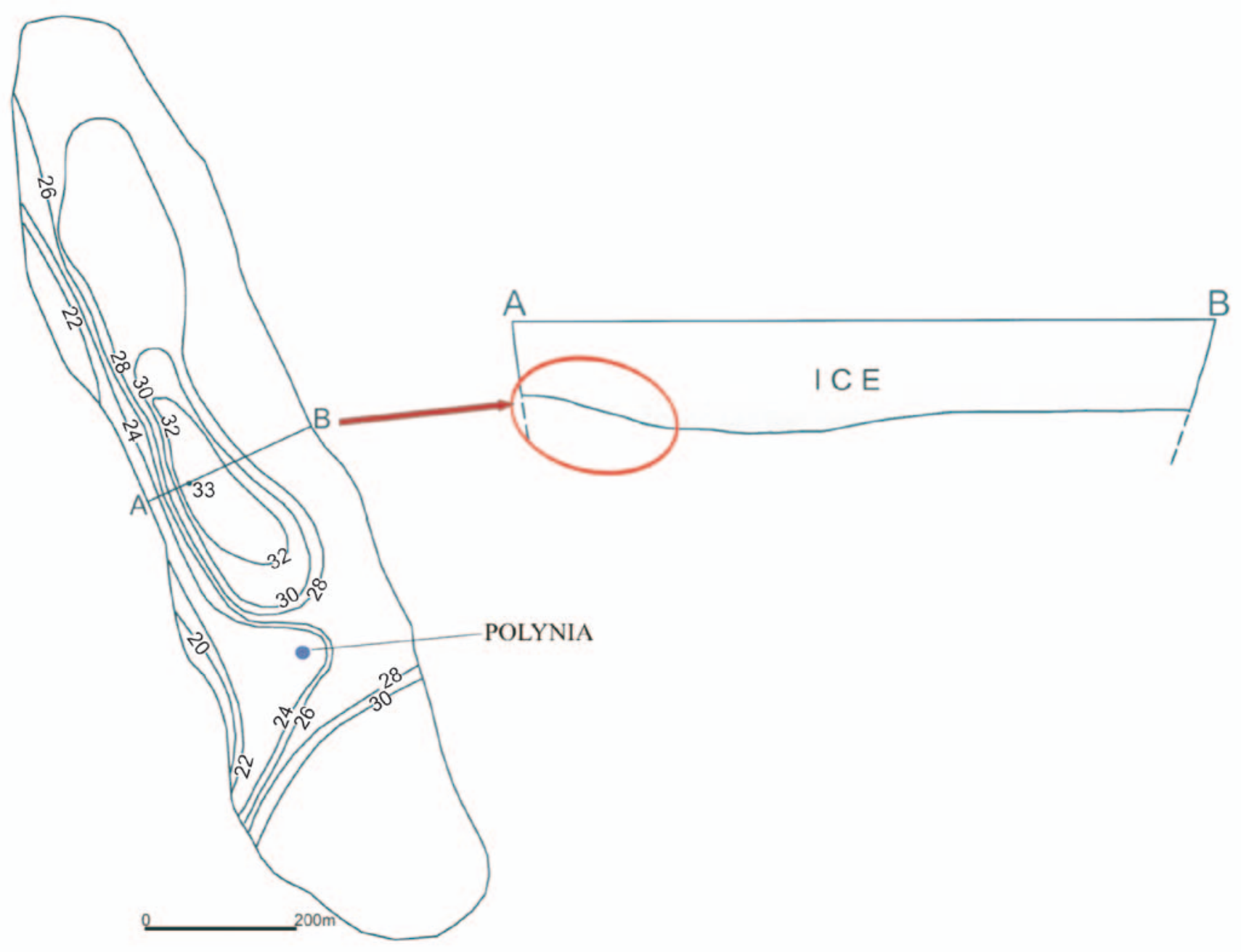

Fig. 4. Differences in the ice cover on Lake Samołęskie and a cross section of the cover

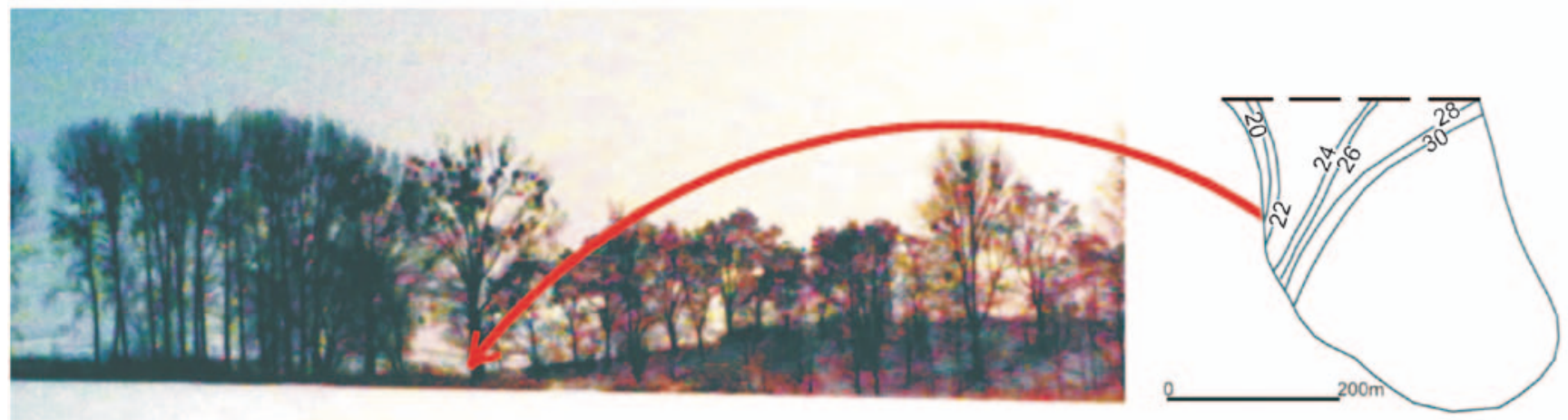

Fig. 5. Differences in the ice cover on Lake Samołęskie in relation to the topography of the lake banks. The right hand side shows the south part of the lake, see 
that the underground water supply is the factor significantly influencing the ice cover thickness. It is well illustrated by the profile presented in Figure 4 . The underground water reaching the bottom layer of ice cover in the west part of the lake causes a reduction in the ice cover thickness. It is a combined result of the higher temperature of the inflowing underground water than that of the lake water and the movement of water thanks to which it reaches the bottom layer of the ice cover. Moreover, as follows from the hydrogeological mapping performed in order to make the hydrogeological map of the area, the water supplying Lake Samołęskie must flow under elevated pressure. This conclusion is confirmed by the presence of polynia (Fig. 6), above the deepest site of the lake, deeper than 20 metres. Formation of ice cover above the polynia is impossible because of the continuous movement of water flowing up from the bottom of the lake basin. Hence, after Choiński (2007) Lake Samołęskie can be treated as a kind of subartesian well, (as the outlets of the water bearing horizon on the lake bottom release water under elevated pressure).

The discontinuity in the ice cover is beneficial not only for the living organisms living under water but also for water birds. When all water reservoirs and rivers in the neighbourhood over the radius of a few kilometres were frozen, this small water enclave was used by over 20 swans.

\section{Conclusions}

Lake Samołęskie well illustrates the influence of local conditions manifested in the character of ice cover formation. The ice cover thickness measurements have proved significant differences over the lake area. The difference between the thickest and the thinnest ice cover was $13 \mathrm{~cm}$, which is more than twice as thick as the ice cover thickness safe for humans, according to Ruman and Rzętała (2005). The variations in ice cover thickness follow from hydrogeological relations and settlement of a part of the lake basin in efficient water bearing horizons. The ice cover variation on Lake Samołęskie indicates that estimation of the ice cover thickness on the basis of a single drilling must be treated with caution. The measurement made at a single site can give a value not representative of the whole ice cover. It should be taken into account in particular when studying the influence of climate changes on the thickness of ice cover. The ice thickness at some sites of a given water reservoir can be determined by the inflow of underground water as it is in Lake Samołęskie, not only by the thermal conditions. Diverse water supply from underground sources can influence the ice cover thickness. Therefore, the lakes at which observation of freezing phenomena are conducted for a number of years should be initially subjected to a detailed examination of the ice cover

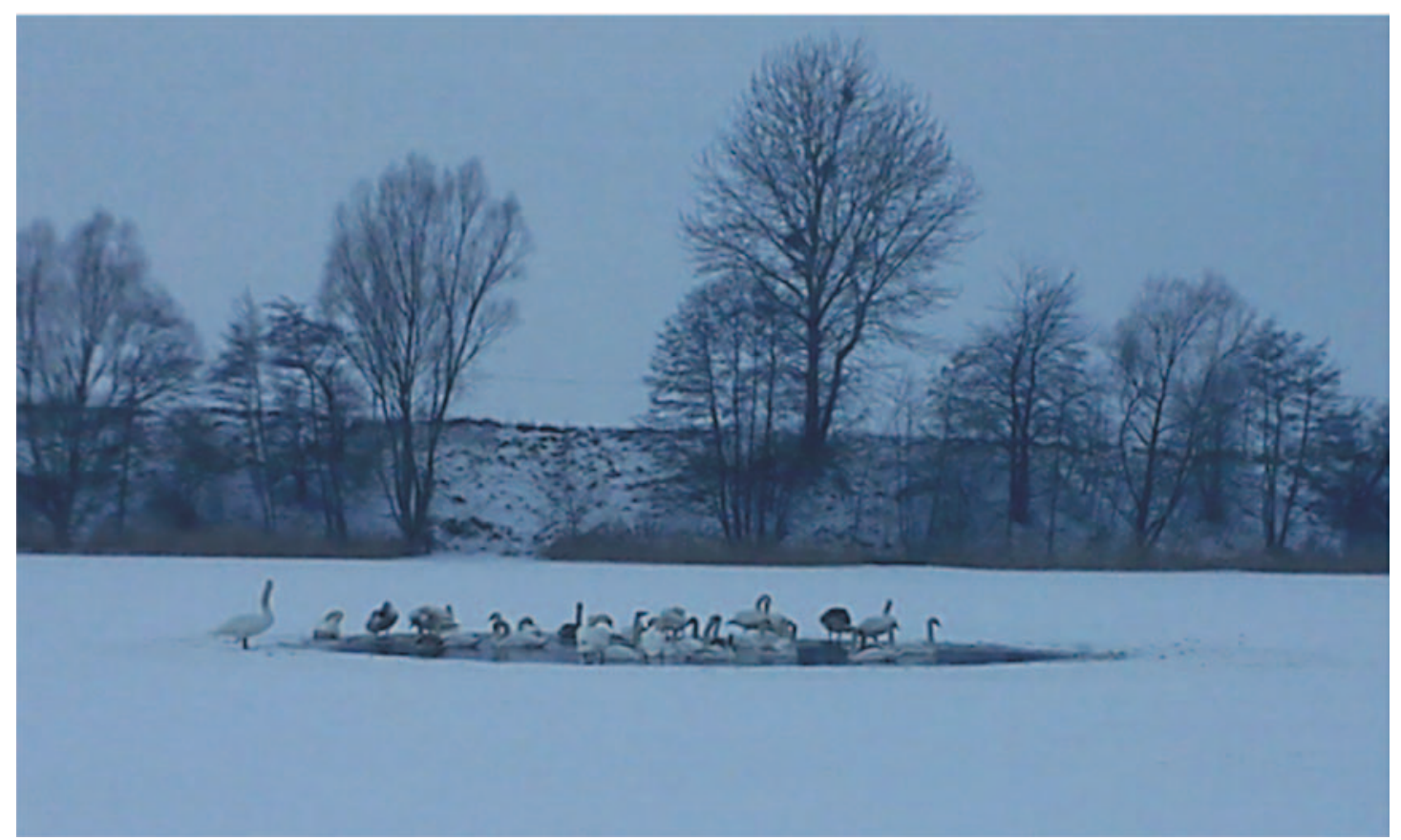

Fig. 6. The polynia on Lake Samołęskie (13.02.2012) 
to choose the optimum site for further single point observations.

The results have encouraged us to conduct further detailed examination of the effect of underground water supply on lake functioning. Analysis of the chemical composition of water collected from different sites and at different depths is planned and measurements of ice cover thickness will be made in a denser network of holes drilled. It is intended to study the variation and processes of freezing both in the seasonal perspective and over many years. The results are expected to supplement the knowledge on the relation between lakes and underground water supply.

\section{References}

Choiński A., 2007, Limnologia fizyczna Polski (Physical limnology of Poland), Wyd. Nauk. UAM, Poznań, p. 547 (in Polish).

Choiński A., Ilyin L, Marszelewski W., Ptak M., 2008, Lakes Supplied by Springs: Selected Examples, Limnol. Rev. 8(4): 145-150.

[IIF] Institute of Inland Fisheries in Olsztyn, 1961, Bathymetric map of Lake Samołęskie, Olsztyn.

Kettle A.J., Hughes C., Unazi G.A., Birch L., Mohie-El-Din H., Jones M.R., 2012, Role of groundwater exchange on the energy budget and seasonal stratification of a shallow temperate lake, J. Hydrol. 470-471: 12-27.

Kondracki J., 1987, Geografia fizyczna Polski (Physical Geography of Poland) PWN, Warszawa, p. 464 (in Polish).

Pękacki S., Ziółkowski M., 1985, Mapa Hydrogeologiczna Polaki 1:200000, arkusz 25-Piła (Hydrogeological Map of Poland, sheet 25-Piła), Wyd. Geol., Warszawa.
Piekarek-Jankowska. H., 1973, Rola jezior rynnowych w kształtowaniu się odpływu wód podziemnych w górnej i środkowej dolinie Rospudy (Part Played by Groove Lakes in Hydrogeology of the Upper and Middle Rospudy Valley), Biul. Inst. Geol. 277: 23-33 (in Polish).

Ruman M., Rzętała M., 2005, Zróżnicowanie pokrywy lodowej zbiorników zaporowych Turowa i Kozłowa Góra w latach hydrologicznych 1975-1996 (Variety of ice cover of Turowa and Kozłowa Góra Dam water Reservoirs in hydrological years 1975-1996) [in:] Jankowski A.T., Rzętała M. (eds), Jeziora i sztuczne zbiorniki wodne: procesy przyrodnicze oraz znacznie społeczno-gospodarcze (Lakes and artificial water reservoirs: natural processes and socio-economic importance), WNoZ UŚ, PTLim, PTG o. Katowice, Sosnowiec: 189-196 (in Polish, English summary).

Sacks L.A., Herman J.S., Konikow L.F., Vela A.L., 1992, Seasonal dynamics of groundwater-lake interactions at Donana National Park, Spain, J. Hydrol. 136(1-4): 123154.

Smerdon B.D., Devito K.J., Mendoza C.A., 2005, Interaction of groundwater and shallow lakes on outwash sediments in the sub-humid Boreal Plains of Canada, J. Hydrol. 314(1-4): 246-262.

Winter T.C., 1999, Relation of streams, lakes, and wetlands to groundwater flow systems, Hydrogeol. J. 7(1): 28-45.

Yin L., Li Y., Huang J., Dong J., Wang X., 2011, Dynamics of interaction of groundwater and Qigai Lake in the Ordos Plateau, P.R. China, Proc. of the International Symposium on Water Resource and Environmental Protection (ISWREP 2011, Xi'an, 20-22 May). Vol. 1: 319-324. 